\title{
A Simple Method for the Simultaneous Determination of Trace Cadmium and Silver in Soil Samples by Dynamic Reaction Cell Inductively Coupled Plasma Mass Spectrometry
}

\author{
Jiangyi Zhang, Yanhui Dong, and Zhifang Xu* \\ Key Laboratory of Shale Gas and Geoengineering, Institute of Geology and Geophysics, \\ Chinese Academy of Sciences, Beijing 100029, P.R. China
}

\section{INTRODUCTION}

Soils are important indicators of environmental changes. Cadmium (Cd) and silver (Ag) are well-known pollutants that are introduced into the environment through both geochemical and anthropogenic activities (1-2), can have toxic effects and affect human life (3-4). Therefore, the accurate monitoring of trace $\mathrm{Cd}$ and $\mathrm{Ag}$ in soils is essential.

Several detection techniques including inductively coupled plasma mass spectrometry (ICP-MS) (5-6), inductively coupled plasma optical emission spectrometry (ICP-OES) (7-8), and atomic absorption spectrometry (AAS) (9-10) have been introduced for the determination of $\mathrm{Cd}$ and $\mathrm{Ag}$ in environmental samples. Compared to AAS or ICP-OES, ICP-MS has excellent detection limits, multi-element capabilities, the ability to measure isotope ratios (11-12), and has emerged as a useful technique for trace $\mathrm{Cd}$ and $\mathrm{Ag}$ analysis of soils. Unfortunately, the concentrations of $\mathrm{Zr}, \mathrm{Mo}, \mathrm{Nb}$, and $\mathrm{Y}$ are many orders of magnitude larger than the $\mathrm{Cd}$ and $\mathrm{Ag}$ in soils, they may form oxide and/or hydroxide ion interferences, such as ${ }^{95} \mathrm{Mo}^{16} \mathrm{O}^{+}$, ${ }^{94} \mathrm{Mo}^{16} \mathrm{OH}^{+},{ }^{94} \mathrm{Zr}^{16} \mathrm{OH}^{+}$on ${ }^{111} \mathrm{Cd}^{+}$, ${ }^{98} \mathrm{Mo}^{16} \mathrm{O}^{+},{ }^{97} \mathrm{Mo}^{16} \mathrm{OH}^{+}$on ${ }^{114} \mathrm{Cd}^{+}$, ${ }^{91} \mathrm{Zr}^{16} \mathrm{O}^{+},{ }^{90} \mathrm{Zr}^{16} \mathrm{OH}^{+},{ }^{89} \mathrm{Y}^{18} \mathrm{O}^{+}$on ${ }^{107} \mathrm{Ag}^{+}$and ${ }^{93} \mathrm{Nb}^{16} \mathrm{O}^{+},{ }^{92} \mathrm{Zr}^{16} \mathrm{OH}^{+}$, ${ }^{92} \mathrm{Mo}^{16} \mathrm{OH}^{+}$on ${ }^{109} \mathrm{Ag}^{+}$. Even interference correction equations are unable to solve interference problems for Cd and Ag (13-14), which

\footnotetext{
*Corresponding autbor.

E-mail: zhangjiangyi@mail.iggcas.ac.cn

Tel: (+86) 10-82998557
}

Fax: (+86) 10-62010846

\begin{abstract}
A simple method based on the dynamic reaction cell (DRC) technology to eliminate the spectral interference in the simultaneous determination of trace cadmium and silver in soil samples by ICP-MS was established. Under the optimized $\mathrm{O}_{2}$ flow rate $\left(2.7 \mathrm{~mL} \mathrm{~min}^{-1}\right)$ and the DRC rejection parameter $\mathrm{RPq}(0.8$ for $\mathrm{Ag}$, 0.7 for $\mathrm{Cd}$ ), the interference caused by $\mathrm{Zr}, \mathrm{Nb}$, and $\mathrm{Mo}$ (such as ${ }^{95} \mathrm{Mo}^{16} \mathrm{O}^{+},{ }^{94} \mathrm{Mo}^{16} \mathrm{OH}^{+}$, ${ }^{94} \mathrm{Zr}^{16} \mathrm{OH}^{+}$on ${ }^{111} \mathrm{Cd}^{+}$and ${ }^{93} \mathrm{Nb}^{16} \mathrm{O}^{+},{ }^{92} \mathrm{Zr}^{16} \mathrm{OH}^{+}$on ${ }^{109} \mathrm{Ag}^{+}$) could be effectively eliminated, and the background signal was reduced up to 100 -fold at $\mathrm{m} / \mathrm{z}$ 109 and 111. The limit of quantitation (LOQ, 10б) for ${ }^{109} \mathrm{Ag}^{+}$and ${ }^{111} \mathrm{Cd}^{+}$was 0.1 and $0.2 \mathrm{ng} \mathrm{g}^{-1}$, respectively. The proposed method was applied to the direct determination of $\mathrm{Ag}$ and $\mathrm{Cd}$ in soil standard reference materials, and the results were in good agreement with the certified values.
\end{abstract}

could lead to significantly erroneous results.

To solve this problem, matrix separation procedures have been proposed. Duan et al. (15) established a new technology combining two separation methods to remove the spectral interferences and matrix effects in soil and geological samples. Liu et al. (16) established load diphenylthiourea foam-selective enrichment for the separation of Au and Ag from other interfering elements in geological samples. Christophe et al. (17) minimized matrix effects and spectral interfer- ences using a sequential procedure in the determination of Cd. However, these methods are time-consuming, expensive, and/or require additional equipment.

An alternative method based on the dynamic reaction cell ${ }^{\mathrm{TM}}$ (DRCTM) techniques has proven to be effective for the alleviation of these metal oxides or hydroxide interferences (18-20). The aim of this work is to utilize $\mathrm{O}_{2}$ as the reaction gas to eliminate the oxide and hydroxide interferences for the simultaneous and accurate determination of $\mathrm{Cd}$ and $\mathrm{Ag}$ in soils by DRC-ICP-MS. The optimization of this technique, the analytical perform-ance, and its application to the simultaneous determination of $\mathrm{Cd}$ and $\mathrm{Ag}$ in standard reference materials are discussed.

\section{EXPERIMENTAI}

\section{Instrumentation}

A PerkinElmer ${ }^{\circledR}$ ELAN ${ }^{\circledR}$ DRC-e (Dynamic Reaction Cell) ICP-MS instrument was used (PerkinElmer Corporation, Shelton, CT, USA), equipped with a cyclonic spray chamber (PC3, Elemental Scientific, USA) sample introduction system, and using a 1.0-mm i.d. quartz injector. The operating parameters of the DRC-ICP-MS used for this work are summarized in Table I. The ICP-MS and DRC conditions were selected and the maximum ion signals of the elements studied while reducing the background to a minimum. A CEM MARS X-press (CEM, Matthews, NC, USA) microwave apparatus, equipped with Teflon ${ }^{\circledR}$ vessels, was used to digest the samples. 


\section{Reagents and Standard Solutions}

High-purity water $\left(18.2 \mathrm{M} \Omega \cdot \mathrm{cm}^{-1}\right)$ was used throughout the work and obtained with a Millipore ${ }^{\circledR}$ Milli-Q ${ }^{\circledR}$ Direct 8 water purification system (Millipore Corporation, France). Nitric acid $\left(\mathrm{HNO}_{3}, 65-70 \%, \mathrm{w} / \mathrm{w}\right.$, 99.9999\%) and hydrofluoric acid (HF, 40\%, 99.99\%) were purchased from the Beijing Chemical Reagent Research Institute. The single-element stock solutions (Ag, Cd, $\mathrm{Zr}$, $\mathrm{Nb}, \mathrm{Mo}$, and $\mathrm{Rh}$ ) were purchased from the National Center for Analysis and Testing of Steel Materials, P.R. China. The DRC $\mathrm{O}_{2}$ gas was purchased from Praxair, Investment Co., Ltd., P.R.China (99.999\% purity). The soil standard reference materials (GBW07402, GBW07403, GBW07404, GBW07406, GBW07407, GBW07408) were obtained from the Institute of Geophysical and Geochemical Exploration, Langfang, P.R. China.

\section{Microwave-assisted Digestion Samples}

Approximately $50 \mathrm{mg}$ of the accurately weighed sample powder was placed into the Teflon ${ }^{\circledR}$ vessel, then $3.0 \mathrm{~mL} \mathrm{HNO}_{3}$ and $1.0 \mathrm{~mL} \mathrm{HF}$ were added, and the vessel was sealed. The digestion program given in Table II was used. After the vessel had cooled, it was opened and heated at $120^{\circ} \mathrm{C}$ to dryness on a hot plate. Then $1.0 \mathrm{~mL} \mathrm{HNO}_{3}$ was added, evaporated to dryness to

TABLE I Instrumental Operating Parameters

\begin{tabular}{|c|c|}
\hline ICP-MS & PerkinElmer ELAN DRC-e \\
\hline Sample introduction & PFA-400 Micro Flow nebulizer \\
\hline Spray chamber & $\begin{array}{l}\text { Cyclonic spray chamber (PC3Peltier Chiller), } \\
\text { room temperature }\end{array}$ \\
\hline Injector tube & $1.0 \mathrm{~mm}$ i.d. quartz \\
\hline RF power & $1350 \mathrm{~W}$ \\
\hline Plasma gas flow & $16 \mathrm{~L} \mathrm{~min}^{-1}$ \\
\hline Auxiliary gas flow & $1.0 \mathrm{~L} \mathrm{~min}^{-1}$ \\
\hline Nebulizer gas flow & $0.81 \mathrm{~L} \min ^{-1}$ \\
\hline $\mathrm{O}_{2}$ reaction gas flow & $2.7 \mathrm{~mL} . \mathrm{min}^{-1}$ \\
\hline Rejection parameter, $\mathrm{q}$ & 0.8 for ${ }^{109} \mathrm{Ag}, 0.7$ for ${ }^{111} \mathrm{Cd}, 0.25$ for ${ }^{103} \mathrm{Rh}^{+}$ \\
\hline Rejection parameter, a & 0 \\
\hline Auto lens & On \\
\hline Dwell time & $50 \mathrm{~ms}$ \\
\hline Sweeps & 32 \\
\hline Readings & 1 \\
\hline Replicate & 3 \\
\hline Cones & $\mathrm{Ni}$ \\
\hline Monitored ions & ${ }^{109} \mathrm{Ag}^{+},{ }^{111} \mathrm{Cd}^{+}$, and ${ }^{103} \mathrm{Rh}^{+}$ \\
\hline
\end{tabular}

TABLE II Microwave Digestion Program for Soil Samples

\begin{tabular}{lccc}
\hline Parameters & First Stage & Second Stage & Third Stage \\
\hline Temperature $\left({ }^{\circ} \mathrm{C}\right)$ & 120 & 160 & 200 \\
Power (W) & 800 & 800 & 1600 \\
Ramp (min) & 10 & 10 & 10 \\
Hold Time (min) & 5 & 5 & 20 \\
\hline
\end{tabular}

help remove $\mathrm{Si}$ and $\mathrm{HF}$. The final solution was made up to $50 \mathrm{~mL}$ by addition of $2 \% \mathrm{HNO}_{3}$ and $0.5 \mathrm{~mL}$ of $1 \mathrm{mg} \mathrm{L}^{-1} \mathrm{Rh}$ internal standard solution. A reagent blank solution was prepared in the same way.

\section{RESULTS AND DISCUSSION}

\section{Spectral Interferences}

It is well-known that high concentrations of $\mathrm{Zr}$, Mo, and $\mathrm{Nb}$ could cause interference by formation of oxides or hydroxides, affecting accuracy in the determination of trace levels of $\mathrm{Cd}$ and $\mathrm{Ag}$. The interferences include ${ }^{95} \mathrm{Mo}^{16} \mathrm{O}^{+}$, ${ }^{94} \mathrm{Mo}^{16} \mathrm{OH}^{+},{ }^{94} \mathrm{Zr}^{16} \mathrm{OH}^{+}$on ${ }^{111} \mathrm{Cd}^{+}$ and ${ }^{93} \mathrm{Nb}^{16} \mathrm{O}^{+},{ }^{92} \mathrm{Zr}^{16} \mathrm{OH}^{+}$on ${ }^{109} \mathrm{Ag}^{+}$. In this work, the interferences were checked under the standard ICP-MS mode, with the results shown in Table III. It can be seen that the signal intensity of $\mathrm{m} / \mathrm{z} 109$ and 111 was 4863 and 1379 cps for $1 \mathrm{ng} \mathrm{mL} \mathrm{m}^{-1} \mathrm{Ag}$ and $\mathrm{Cd}$; however, $500 \mathrm{ng} \mathrm{mL}^{-1} \mathrm{Nb}$ and $2000 \mathrm{ng} \mathrm{mL}^{-1} \mathrm{Zr}$ was the equivalent of 9.43 and 0.42

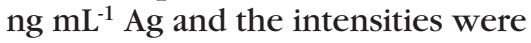
45838 and 2034 at $\mathrm{m} / \mathrm{z} 109$, respectively. And $500 \mathrm{ng} \mathrm{mL}^{-1} \mathrm{Mo}$ and $2000 \mathrm{ng} \mathrm{mL}^{-1} \mathrm{Zr}$ was the equivalent of 1.03 and $1.48 \mathrm{ng} \mathrm{mL}^{-1} \mathrm{Cd}$ with intensities of 1419 and 2042 at $\mathrm{m} / \mathrm{z}$ 111 , respectively. Therefore, the presence of these elements results in significant positive bias for the simultaneous determination of $\mathrm{Ag}$ and $\mathrm{Cd}$ and the interferences should be removed.

\section{Removal of Spectral Interferences by $\mathrm{O}_{2}$ DRC}

In this work, the DRC technology was used to eliminate oxide/ hydroxide interference for $\mathrm{Ag}$ and Cd determination with $\mathrm{O}_{2}$ as the reaction gas. The flow rates of the reaction gas and the DRC rejection parameter $\mathrm{q}(\mathrm{RPq})$ were two important parameters. The effect of these parameters on the signal of $1 \mathrm{ng}$ $\mathrm{mL}^{-1} \mathrm{Ag}, \mathrm{Cd}$, and the matrix blank at $\mathrm{m} / \mathrm{z} 109$ and 111 are shown in Figure 1. In this figure, the back- 
ground equivalent concentration (BEC) was used as the criterion for determining the optimum conditions while monitoring ${ }^{109} \mathrm{Ag}^{+}$and ${ }^{111} \mathrm{Cd}^{+}$. The solution of $500 \mathrm{ng} \mathrm{mL}^{-1}$

\section{TABLE III}

Interferences on $\mathrm{m} / \mathrm{z} 109$ and 111 With Different Elements (n=5)

\begin{tabular}{lrcrc}
\hline & \multicolumn{2}{c}{$\mathrm{m} / \mathrm{z} 109$} & \multicolumn{2}{c}{$\mathrm{m} / \mathrm{z} 111$} \\
& $\begin{array}{c}\text { Signal } \\
(\mathrm{cps})\end{array}$ & $\begin{array}{c}\text { Equivalent } \\
\left(\mathrm{ng} \mathrm{mL} \mathrm{mL}^{-1}\right)\end{array}$ & $\begin{array}{c}\text { Signal } \\
\text { Intensity } \\
(\mathrm{cps})\end{array}$ & $\begin{array}{c}\text { Equivalent } \\
\left(\mathrm{ng} \mathrm{mL}^{-1}\right)\end{array}$ \\
\hline $1 \% \mathrm{HNO}_{3}$ & $25 \pm 2$ & 0.005 & $21 \pm 1$ & 0.02 \\
$1 \mathrm{ng} \mathrm{mL}-1 \mathrm{Ag}$ & $4863 \pm 42$ & 1 & - & - \\
$1 \mathrm{ng} \mathrm{mL}-1 \mathrm{Cd}$ & - & - & $1379 \pm 19$ & 1 \\
$500 \mathrm{ng} \mathrm{mL}^{-1} \mathrm{Nb}$ & $45,838 \pm 380$ & 9.43 & $118 \pm 5$ & 0.09 \\
$500 \mathrm{ng} \mathrm{mL}^{-1} \mathrm{Mo}$ & $35 \pm 4$ & 0.007 & $1419 \pm 31$ & 1.03 \\
$2000 \mathrm{ng} \mathrm{mL}^{-1} \mathrm{Zr}$ & $2034 \pm 25$ & 0.42 & $2042 \pm 27$ & 1.48 \\
\hline
\end{tabular}

$\mathrm{Nb}, 500 \mathrm{ng} \mathrm{mL} \mathrm{mo}^{-1} \mathrm{Mo}$, and $2000 \mathrm{ng}$ $\mathrm{mL}^{-1} \mathrm{Zr}$ was treated as matrix blank to simulate the interfering elements.

\section{Atomic Spectroscopy \\ $\bigcirc$ Vol. 37(4), July/August 2016}

As shown in Figures 1a and 1c, with an increase in $\mathrm{O}_{2}$ flow rate, the signal intensity of the $\mathrm{Ag}+$ matrix, $\mathrm{Cd}+$ matrix, and matrix blank significantly increased, and then decreased. The reason may be that the formation of more monoxides or hydroxides interferes with the determination at $\mathrm{m} / \mathrm{z} 109$ and 111 at the low $\mathrm{O}_{2}$ flow rate. However, the interference was rapidly reduced due to the formation of more dioxide or trioxide at the high $\mathrm{O}_{2}$ flow rate $(1,21-22)$. When the $\mathrm{O}_{2}$ flow rate was greater than 2.6 $\mathrm{mL} \mathrm{min}^{-1}$, the signal intensity began to level off, and the value of BEC was at a minimum. Therefore, the
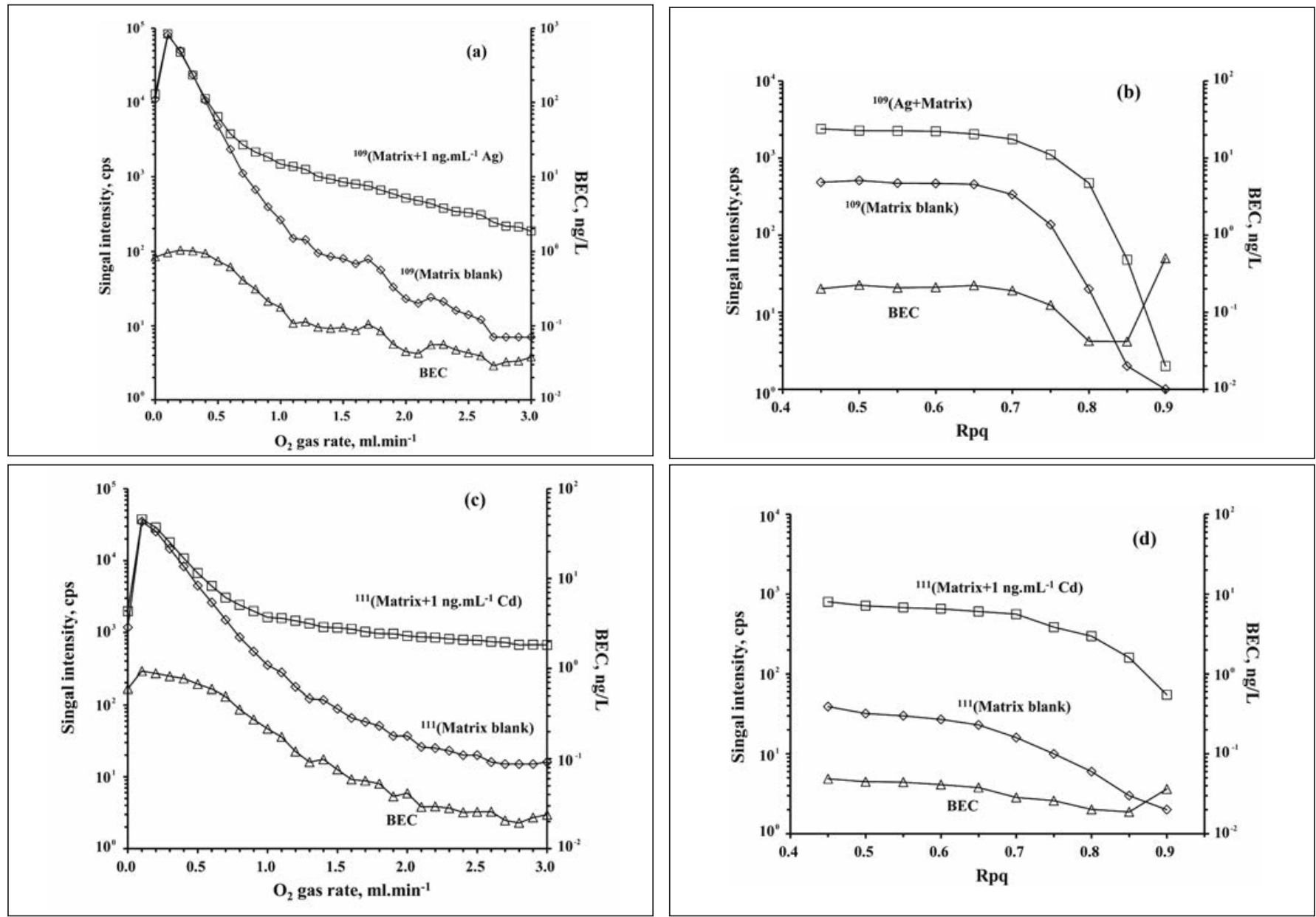

Fig. $1(a, b, c, d)$. Effects of $\mathrm{O}_{2}$ gas flow rate $(a, c)$ and rejection parameter $q(\mathrm{RPq})$ value $(b, d)$ on signal intensity of

${ }^{109}$ Ag+matrix, ${ }^{111} \mathrm{Cd}+$ matrix, matrix blank, and background equivalent concentration (BEC). The concentrations of Ag and Cd were $1 \mathrm{ng} \mathrm{mL}^{-1}$. A solution of $500 \mathrm{ng} \mathrm{mL}^{-1} \mathrm{Nb}, 500 \mathrm{ng} \mathrm{mL}^{-1} \mathrm{Mo}$ and $2000 \mathrm{ng} \mathrm{mL}^{-1} \mathrm{Zr}$ was used as the matrix blank. 
optimized $\mathrm{O}_{2}$ flow rate of $2.7 \mathrm{~mL}$ $\mathrm{min}^{-1}$ was selected. At this flow rate, the interference ions could be reduced up to 100 -fold for ${ }^{109} \mathrm{Ag}$ and ${ }^{111} \mathrm{Cd}$.

The RPq values are important to filter out unwanted precursors of the interfering species from the ion beam and eliminate interferences created in the cell by the reaction gas. With $\mathrm{RPq}<0.7$ (Figure $1 \mathrm{~b}$ ) and $<0.65$ (Figure $1 \mathrm{~d}$ ), the singal intensity of $\mathrm{Ag}, \mathrm{Cd}$, and the matrix blank tended to be constant. However, with an RPq value $>0.7$ (Figure 1b) and $>0.65$ (Figure 1d), the signal intensity of $\mathrm{Ag}, \mathrm{Cd}$, and the matrix blank began to decrease. The optimized $\mathrm{RPq}$ value was 0.8 for ${ }^{109} \mathrm{Ag}$ and 0.7 for ${ }^{111} \mathrm{Cd}$, where the best background equivalent concentrations (BEC) of ${ }^{109} \mathrm{Ag}$ and ${ }^{111} \mathrm{Cd}$ were 0.02 and $0.03 \mathrm{ng} \mathrm{mL}^{-1}$, respectively.

\section{Analytical Performance}

Under the optimized experimental conditions, the limit of quantitation (LOQ and ten times the standard deviation of the produce blank) was $0.1 \mathrm{ng} \mathrm{g}^{-1}$ for $\mathrm{Ag}$ and 0.2 $\mathrm{ng} \mathrm{g}^{-1}$ for $\mathrm{Cd}$. The LOQ is expressed as the concentration in the samples, thereby taking into account the dilution factor (1000). This sensitivity is sufficient for the trace Ag and Cd determination in soils. The relative standard deviation (RSD) was calculated based on triplicate sam- ple digestions and analyses, and was generally less than 5\%.

\section{Soil Samples Analysis}

Table IV summarizes the results for six soil standard reference materials (GBW07402-04, GBW0740608) which were processed by microwave-assisted acid digestion and followed by DRC-ICP-MS analysis. The obtained values were in good agreement with the certified values by the established method. However, the values using standard mode (i.e., no cell gas or RPq) were much greater than the certified values. This demonstrated that the polyatomic interference could be effectively eliminated by DRC-ICPMS without the correction.

\section{CONCLUSION}

A simple method has been developed for the direct simultaneous determination of trace $\mathrm{Ag}$ and $\mathrm{Cd}$ in soil samples by DRC-ICP-MS after microwave-assisted acid digestion. The spectral interferences caused by $\mathrm{Zr}, \mathrm{Nb}$, and Mo were successfully eliminated by oxide reaction with $\mathrm{O}_{2}$ in the DRC. This method could be used in environmental samples analysis.

\section{ACKNOWLEDGMENT}

This research was supported by the Strategic Priority Research Program of the Chinese Academy of
Sciences (Grant No. XDB10030601). Partial support was also provided by The State Key Laboratory for Coal Resources and Safe Mining, China University of Mining \& Technology (Grant No.

SKLCRSM12KFA02) and the Beijing Natural Science Foundation (Grant No. 8162042).

$\overline{\text { Received January 16, } 2016 .}$

\section{REFERENCES}

1. W. Guo, S. H. Hu, J. Y. Zhang, and H. F. Zhang, Sci. Total Environ. 409, 2981 (2011).

2. M. Ghazaghi, H. Shirkhanloo, H. Z. Mousavi, and A. M. Rashidi, Microchim. Acta 182, 1263 (2015).

3. Y. Luo, E. Dabek-Zlotorzynska, V. Celo, D. C. G. Muir, and L. Yang, Anal. Chem. 82, 3922 (2010).

4. A. C. Davis, P. Wu, X. Zhang, X. Hou, and B. T. Jones, Appl. Spectrosc. Rev. 41, 35 (2006).

5. Q. Xu, W. Guo, L. L. Jin, Q. H. Guo, and S. H. Hu, J. Anal. At. Spectrom. 30, 2010 (2015).

6. Y. Wang, L. A. Baker, and I. D. Brindle, Talanta 148, 419 (2016).

7. S. Karlsson, V. Sjöberg, and A. Ogar, Talanta 135, 124 (2015).

8. I. J. Cindric, I. Krizman, M. Zeiner, S. Kampic, G. Medunic, and G. Stingeder, Food Chem. 135, 2675 (2012).

TABLE IV

Mean and Standard Deviation ( $(n=3)$ for Ag and Cd in Soil SRMs ( $\mu \mathrm{g} \mathrm{g}^{-1}$ ) by Standard Mode and DRC-ICP-MS

\begin{tabular}{|c|c|c|c|c|c|c|c|c|c|c|c|}
\hline \multirow[t]{2}{*}{$\begin{array}{l}\text { Reference } \\
\text { Materials }\end{array}$} & \multirow[t]{2}{*}{ Soil } & \multirow[t]{2}{*}{$\mathrm{Zr} / \mathrm{Ag}$} & \multirow[t]{2}{*}{$\mathrm{Nb} / \mathrm{Ag}$} & \multirow[t]{2}{*}{$\mathrm{Zr} / \mathrm{Cd}$} & \multirow[t]{2}{*}{$\mathrm{Mo} / \mathrm{Cd}$} & \multicolumn{3}{|c|}{$\begin{array}{l}\text { Ag, } \mathrm{g} \mathrm{g}^{-1}(\text { Mean } \pm \mathrm{SD}) \\
\text { This Work }\end{array}$} & \multicolumn{3}{|c|}{$\begin{array}{c}\mathrm{Cd}, \mathrm{g} \mathrm{g}^{-1}(\text { Mean } \pm \mathrm{SD}) \\
\text { This work }\end{array}$} \\
\hline & & & & & & ICP-MS & DRC-ICP-MS & Certified Value & ICP-MS & DRC-ICP-MS C & Certified Value \\
\hline GBW07402 & Chestnut soil & 4056 & 500 & 3085 & 13.8 & $0.359 \pm 0.013$ & $0.055 \pm 0.003$ & $0.054 \pm 0.007$ & $0.164 \pm 0.011$ & $0.072 \pm 0.008$ & $0.071 \pm 0.014$ \\
\hline GBW07403 & $\begin{array}{l}\text { Yellow brown } \\
\text { soil }\end{array}$ & 2703 & 102 & 4100 & 5.2 & $0.185 \pm 0.008$ & $0.093 \pm 0.004$ & $0.091 \pm 0.007$ & $0.186 \pm 0.009$ & $0.063 \pm 0.005$ & $0.060 \pm 0.009$ \\
\hline GBW07404 & Limestone soil & 7143 & 543 & 1429 & 7.4 & $0.567 \pm 0.012$ & $0.072 \pm 0.006$ & $0.070 \pm 0.011$ & $1.05 \pm 0.05$ & $0.35 \pm 0.04$ & $0.35 \pm 0.06$ \\
\hline GBW07406 & Red yellow soil & 1100 & 135 & 1692 & 1.4 & $0.555 \pm 0.011$ & $0.21 \pm 0.02$ & $0.20 \pm 0.02$ & $0.89 \pm 0.02$ & $0.14 \pm 0.02$ & $0.13 \pm 0.03$ \\
\hline GBW07407 & Latosol soil & 5579 & 1123 & 3975 & 36.3 & $0.791 \pm 0.008$ & $0.057 \pm 0.004$ & $0.057 \pm 0.011$ & $0.62 \pm 0.03$ & $0.09 \pm 0.01$ & $0.08 \pm 0.02$ \\
\hline GBW07408 & Loess soil & 3817 & 250 & 1762 & 8.9 & $0.331 \pm 0.007$ & $0.059 \pm 0.003$ & $0.060 \pm 0.009$ & $0.93 \pm 0.03$ & $0.13 \pm 0.01$ & $0.13 \pm 0.02$ \\
\hline
\end{tabular}




\section{Atomic $_{\text {Spectroscopy }}^{\text {to }}$ \\ 1 Vol. 37(4), July/August 2016}

9. H. Cui, W. Guo, M. T. Cheng, P. Zhang, L L. Jin, Q. H. Guo, and S. H. Hu, Anal. Methods 7, 970 (2015).

10. C. Du, L. Luo, W. Guo, L. L. Jin, B. Chen, and S. H. Hu, At. Spectrom. 35, 141 (2015).

11.W. Guo, S. H. Hu, Z. W. Wu, G. Y. Lan, L. L. Jin, X. G. Pang, J. C. Zhan, B. Chen, and Z. Y. Tang, J. Anal. At. Spectrom. 30, 986(2015).

12. S. M. Cruz, L. Schmidt, F. M. D. Nora, M. F. Pedrotti, C. A. Bizzi, J. S. Barin, and E. M. M. Flores, Microchem. J. 123,28(2015).

13. C. J. Park, K. H. Cho, J. K. Suh, and M. S. Han, J. Anal. At. Spectrom. 15, 567(2000).

14. J. Xu, Z. C. Hu, Y. S. Liu, S. H. Hu, H. L. Yuan, and S. Gao, Chinese J. Anal. Chem. 36, 1493 (2008).

15. T. C. Duan, X. J. Song, P. G. Guo, H. F. Li, L. H. Pan, H. T. Chen, and J. W. Xu, J. Anal. At. Spectrom. 22, 403 (2007).

16. X. L. Liu, W. J. Sun, T. Y. Wen, T. F. Wang, W. Z. Sun, Y. X. Li, and J. Guo, Chinese J. Anal. Chem. 43, 1371 (2015).

17. W. Christophe and D. Francis, Measurement 46, 2348 (2013).

18. S. D. Tanner, V. I. Baranov, and D. R. Bandura, Spectrochim. Acta B, 57, 1361 (2002).

19. D. R. Bandura, V. I. Baranov, and S. D. Tanner, Fresenius J. Anal. Chem. 370,454 (2001).

20. F. Ardini, F. Soggia, F. Rugi, R. Udisti, and M. Grotti, J Anal At Spectrom. 25, 1588 (2010).

21. W. Guo, S. H. Hu, J. Zhao, S. S. Jin, W. J. Liu, and H. F. Zhang, Microchem. J. 97, 154 (2011).

22. W. Guo, S. H. Hu, Y. F. Xiao, H. F. Zhang, and X. J. Xie, Chemosphere 81,1463 (2010). 